\title{
Preface
}

\section{The Alzheimer's Disease-Diabetes Angle: Inevitable Fate of Aging or Metabolic Imbalance Limiting Successful Aging}

\author{
Angelika Bierhaus* and Peter P. Nawroth \\ Department of Medicine I and Clinical Chemistry, University of Heidelberg, Heidelberg, Germany
}

\begin{abstract}
Modern societies face the increasing burden of agerelated diseases, in particular Alzheimer's disease (AD) and type 2 diabetes (T2D). While numerous epidemiological studies have described the incidence of both diseases in the Western world and extensively defined common environmental risk factors, only little is known on the pathomechanisms linking both diseases [1-3]. Thus, it is not yet clear whether both diseases represent the endpoint of aged, exhausted, and dysfunctional cells having reached their maximal life expectancy or whether $\mathrm{AD}$ and $\mathrm{T} 2 \mathrm{D}$ are the consequences of living in superabundance including excessive food supply, work demands, psychosocial stress, and an excessive sedentary life style [4-9]. Evidence for the latter is provided by the fact that high adiposity increases the risk of $\mathrm{AD}[10-12]$ and $\mathrm{T} 2 \mathrm{D}[10,13]$ and implies that the progressive loss of energy balance is one underlying pathomechanism of both diseases.

Interestingly, mammalian hibernators such as ground squirrels and hamsters demonstrate comparable and annual recurrent periods of obesity with concomitant insulin resistance and key features of $\mathrm{AD}$ such as tau phosphorylation $[14,15]$. These pathologies, however, are reversed by a time-dependent metabolic shift be-
\end{abstract}

* Corresponding author: Angelika Bierhaus, $\mathrm{PhD}$, Department of Medicine I, University of Heidelberg, Im Neuenheimer Feld 410, 69120 Heidelberg, Germany. Tel.: +496221 564752; Fax: +496221 564754; E-mail: angelika_bierhaus@med.uni-heidelberg.de. tween carbohydrate- and fat-based metabolism, a delicate balance of kinases and phosphatases and changes in gene expression [15-17]. While massive fat depots serve as the main source of metabolic fuel throughout the winter [18], phosphorylation of tau during obligate hibernation seems to be a reversible consequence of hypothermia $[19,20]$. These changes gradually decrease over a period of months until the animals emerge from hibernation each spring [18]. Thus, fat storage and tau phosphorylation occur predictably on an annual basis, but subsequent fasting depletes fat during the course of winter and ensures that each spring the obese hibernator emerges lean [18]. Another example for a phylogenetic conserved adaptive response to energetic stress is provided by hummingbirds [21], which consume a high sugar diet and seasonally develop hyperglycemia and obesity, which is normalized during the breeding season [21]. Thus, hibernating mammals and hummingbirds provide an extreme example of the utility of accumulating body resources in nutrient-rich times for later use during times of fasting.

These observations, however, indicate that mechanisms have to exist that enable cells to re-program their metabolism and maintain accurate energy balance despite repeated situations of excessive energy surplus. Fasting periods might also change and/or normalize gene expression patterns and activate cellular defense mechanisms that protect cells from being impaired by subsequent nutrition supply [18]. Noteworthy, centenarians seem to be equipped with gene variants that 
allow them to optimize the energy balance and to minimize the effects of exposure to environmental stressors [22].

Features of the metabolism in starvation, hibernation, and various conditions of energy deprivation have led to the definition of the deprivation syndrome as a phylogenetically conserved adaptive response to energetic stress, which is characterized by hypometabolism, oxidative stress, and adjustments of the glucose-fatty acid cycle [23].

Several pathological features have been identified as common denominators of $\mathrm{AD}$ and $\mathrm{T} 2 \mathrm{D}$ including impaired glucose/energy metabolism, altered insulinsignaling pathways, mitochondrial dysfunction, oxidative stress, and inflammation. There is also increasing evidence that posttranslational modifications such as sumoylation and glycation might contribute to gene expression changes and the loss of cellular function in situations, in which energy balance cannot be restored. In this context it is of particular interest that amyloid$\beta$ peptides, causing neurodegeneration and cognitive decline in $\mathrm{AD}$ [24], and advanced glycation end products (AGEs), accumulating in T2D [25,26], are ligands of the receptor for AGEs (RAGE) [27-31], known to perpetuate inflammation, to increase oxidative stress and to mediate downregulation of protective cellular mechanisms in situations of ligand excess [29]. Thus, RAGE might play a central role in converting the reversible obesity, accompanying insulin resistance and Alzheimer-like pathologies of natural hibernation into the pandemic of human obesity, metabolic syndrome, $\mathrm{AD}$, and $\mathrm{T} 2 \mathrm{D}$.

The identification and functional characterization of these checkpoints in model organisms and their confirmation in prospective clinical studies holds great promise, that understanding the common pathways of $\mathrm{AD}$ and T2D will provide progress in both fields of research. This special issue summarizes the current knowledge on pathways triggered by oxidative stress, reactive metabolites, inflammation, and RAGE in AD and T2D and addresses common features of both in model organisms such as C. elegans, in experimental rodent models, and from the clinical perspective.

\section{ACKNOWLEDGMENTS}

Supported by grants from the Network Aging Research (to $\mathrm{AB}$ ) and the Hopp-foundation (to $\mathrm{AB}$ and PPN).

\section{REFERENCES}

[1] Neumann KF, Rojo L, Navarrete LP, Farias G, Reyes P, Maccioni RB (2008) Insulin resistance and Alzheimer's disease: molecular links \& clinical implications. Curr Alzheimer Res 5, 438-447.

[2] Milionis HJ, Florentin M, Giannopoulos S (2008) Metabolic syndrome and Alzheimer's disease: a link to a vascular hypothesis? CNS Spectr 13, 606-613.

[3] Li L, Holscher C (2007) Common pathological processes in Alzheimer disease and type 2 diabetes: a review. Brain Res Rev 56, 384-402.

[4] Morse DR (2006) Live longer, live better: lifestyle diseases and their prevention, part 2. Dent Today 25, 100, 102-103.

[5] Pasinetti GM, Zhao Z, Qin W, Ho L, Shrishailam Y, Macgrogan D, Ressmann W, Humala N, Liu X, Romero C, Stetka B, Chen L, Ksiezak-Reding H, Wang J (2007) Caloric intake and Alzheimer's disease. Experimental approaches and therapeutic implications. Interdiscip Top Gerontol 35, 159-175.

[6] Pope SK, Shue VM, Beck C (2003) Will a healthy lifestyle help prevent Alzheimer's disease? Annu Rev Public Health 24, 111-132.

[7] Biessels GJ, Kappelle LJ (2005) Increased risk of Alzheimer's disease in Type II diabetes: insulin resistance of the brain or insulin-induced amyloid pathology? Biochem Soc Trans 33, 1041-1044.

[8] Janson J, Laedtke T, Parisi JE, O'Brien P, Petersen RC, Butler PC (2004) Increased risk of type 2 diabetes in Alzheimer disease. Diabetes 53, 474-481.

[9] Pasquier F, Boulogne A, Leys D, Fontaine P (2006) Diabetes mellitus and dementia. Diabetes Metab 32, 403-414.

[10] Luchsinger JA (2008) Adiposity, hyperinsulinemia, diabetes and Alzheimer's disease: an epidemiological perspective. Eur J Pharmacol 585, 119-129.

[11] Luchsinger JA, Mayeux R (2007) Adiposity and Alzheimer's disease. Curr Alzheimer Res 4, 127-134.

[12] Whitmer RA, Gunderson EP, Quesenberry CP, Jr., Zhou J, Yaffe K (2007) Body mass index in midlife and risk of Alzheimer disease and vascular dementia. Curr Alzheimer Res 4, 103-109.

[13] Rader DJ (2007) Effect of insulin resistance, dyslipidemia, and intra-abdominal adiposity on the development of cardiovascular disease and diabetes mellitus. Am J Med 120, S12-18.

[14] Hartig W, Stieler J, Boerema AS, Wolf J, Schmidt U, Weissfuss J, Bullmann T, Strijkstra AM, Arendt T (2007) Hibernation model of tau phosphorylation in hamsters: selective vulnerability of cholinergic basal forebrain neurons - implications for Alzheimer's disease. Eur J Neurosci 25, 69-80.

[15] Su B, Wang X, Drew KL, Perry G, Smith MA, Zhu X (2008) Physiological regulation of tau phosphorylation during hibernation. J Neurochem 105, 2098-2108.

[16] Heininger K (2000) A unifying hypothesis of Alzheimer's disease. IV. Causation and sequence of events. Rev Neurosci 11 Spec No, 213-328.

[17] Andrews MT, Russeth KP, Drewes LR, Henry PG (2008) Adaptive mechanisms regulate preferred utilization of ketones in the heart and brain of a hibernating mammal during arousal from torpor. Am J Physiol Regul Integr Comp Physiol, in press.

[18] Martin SL (2008) Mammalian hibernation: a naturally reversible model for insulin resistance in man? Diab Vasc Dis Res 5, 76-81.

[19] Avila J, Diaz-Nido J (2004) Tangling with hypothermia. Nat Med 10, 460-461. 
[20] Planel E, Tatebayashi Y, Miyasaka T, Liu L, Wang L, Herman M, Yu WH, Luchsinger JA, Wadzinski B, Duff KE, Takashima A (2007) Insulin dysfunction induces in vivo tau hyperphosphorylation through distinct mechanisms. $\mathrm{J} \mathrm{Neu-}$ rosci $27,13635-13648$.

[21] Adhikari N, Charles N, Lehmann U, Hall JL (2006) Transcription factor and kinase-mediated signaling in atherosclerosis and vascular injury. Curr Atheroscler Rep 8, 252-260.

[22] Ostan R, Bucci L, Capri M, Salvioli S, Scurti M, Pini E, Monti D, Franceschi C (2008) Immunosenescence and immunogenetics of human longevity. Neuroimmunomodulation 15, 224-240.

[23] Heininger K (2002) Aging is a deprivation syndrome driven by a germ-soma conflict. Ageing Res Rev 1, 481-536.

[24] Yankner BA, Lu T (2008) Amyloid beta-protein toxicity and the pathogenesis of Alzheimer's disease. J Biol Chem, in press.

[25] Su J, Lucchesi PA, Gonzalez-Villalobos RA, Palen DI, Rezk BM, Suzuki Y, Boulares HA, Matrougui K (2008) Role of advanced glycation end products with oxidative stress in resistance artery dysfunction in type 2 diabetic mice. Arterioscler Thromb Vasc Biol 28, 1432-1438.

[26] Bierhaus A, Hofmann MA, Ziegler R, Nawroth PP (1998) AGEs and their interaction with AGE-receptors in vascular disease and diabetes mellitus. I. The AGE concept. Cardiovasc Res 37, 586-600.

[27] Schmidt AM, Hori O, Brett J, Yan SD, Wautier JL, Stern D (1994) Cellular receptors for advanced glycation end products. Implications for induction of oxidant stress and cellular dysfunction in the pathogenesis of vascular lesions. Arterioscler Thromb 14, 1521-1528.

[28] Schmitt HP (2006) epsilon-Glycation, APP and Abeta in ageing and Alzheimer disease: a hypothesis. Med Hypotheses 66, 898-906.

[29] Bierhaus A, Humpert PM, Morcos M, Wendt T, Chavakis T, Arnold B, Stern DM, Nawroth PP (2005) Understanding RAGE, the receptor for advanced glycation end products. $J$ Mol Med 83, 876-886.

[30] Yan SF, D'Agati V, Schmidt AM, Ramasamy R (2007) Receptor for Advanced Glycation Endproducts (RAGE): a formidable force in the pathogenesis of the cardiovascular complications of diabetes \& aging. Curr Mol Med 7, 699-710.

[31] Yan SF, Ramasamy R, Schmidt AM (2008) Mechanisms of disease: advanced glycation end-products and their receptor in inflammation and diabetes complications. Nat Clin Pract Endocrinol Metab 4, 285-293. 